\title{
INVESTASI PASAR MODAL, MEMAHAMI INVESTOR, EMITEN DAN SEKURITAS
}

\author{
Oleh \\ Raendhi Rahmadi*)
}

\section{Abstrak}

Pasar modal membawa berbagai manfaat bagi para pelakunya, terutama bagi perusahaan yang menjual efek atau sahamnya dengan memanfaatkan pasar modal sebagai tempat untuk mendapatkan modal dengan menjual saham perusahaan kepada para investor di dalam pasar modal. Perusahaan ini dikenal sebagai Emiten dan yang memasarkan atau perantara atas penjualan saham dipasarmodal adalah sekuritas. Antara Emiten dan sekuritas memiliki hubungan yang saling berkaitan erat dalam transaksi dipasar modal, begitu pula dengan berbagai elemen lainnya yang berada dipasar modal. Maka untuk menerangkan hal ini dalam Jurnal ini disampaikan dalam bentuk deskriptif. Hal yang akan disampaikan akan menjelaskan berbagai jenis pelaku dan fungsi lembaga yang berperan dalam pasar modal tersebut, yang akan dijelaskan satu persatu dalam tulisan ini. Hal ini akan mengenalkan pembaca pada pelaku pasar modal fungsi dari tiap lembaga tersebut untuk membuat pembaca memiliki informasi atas berbagaimacam hal yang terdapat di pasar modal, kuhusnya Pasar Modal Indonesia.

\section{Kata Kunci : Pasar Modal, Lembaga Pasar Modal, Investasi}

\section{A.PENDAHULUAN}

Indonesia adalah saksi sejarah atas pasar modal pertama didunia, meskipun bukanlah pelaku sejarah namun aset yang menjadi objek yang di perdagangkan berada di Indonesia ketika belanda membuat suatu perusahaan multi nasional pertama bernama Verenigne Oost-Indische Compagnie atau yang akrab namanya di telinga kita sebagai V.O.C. dan dituturkan oleh orang pribumi sebagai Kompeni. Perusahaan inilah yang menjadi perusahaan awal yang kepemilikannya dijual di Ansterdam Belanda, setidaknya itu terjadi pada tahun 1602. Sedangkan pasar modal sendiri mulai ada di Indonesia sejak zaman penjajahan Belanda yaitu pada tahun 1912 dimana pasar modal tersebut menjual sejumlah hak penyertaan kepemilikan atas perusahaan milik orang belanda yang ada di Indonesia serta juga obligasi pemerintah hindia belanda. Pada era pasca kemerdekaan kesadaran perlunya membuka pasar saham telah disadari oleh bapak pendiri bangsa maka maka pada tahun 1951 Indonesia mulai memiliki Pasar Modal sendiri, hal ini ditandai dengan Undang Undang Darurat Nomor 13 tahun 1951 yang kemudian di gantikan dengan Undang undang Nomor 15 tahun 1952 yang mengatur tentang pasar modal, yang kemudian digantikan lagi oleh aturan setelahnya.

Ketika kita melihat sejarah yang merentang mewarnai perjalanan pasar modal di Indonesia, maka Sejarah Pasar modal di Indonesia tampaknya belum seabad umurnya, namun pertumbuhan yang terjadi tampak cukup dinamis dan menjanjikan. Hal ini membuat penulis merasa penting untuk memberikan

*) Penulis adalah Dosen Fakultas Hukum

Universitas Islam Syekh Yusuf 
penjelasan mengenai Investasi Pasar Modal dalam jurnal Ilmiah ini baik dari sisi konsepsi dan perkembangan yang terjadi yang tentu saja berdasarkan perspektif hukum Indonesia. Maka untuk memulai hal tesebut dalam jurnal ini akan disampaikan pemahaman pasar modal mengenai hal yang urgen untuk dipahami yaitu mengenai Pasar Modal itu sendiri, lalu berbagai lembaga yang ada di dalamnya yang juga akan menjelaskan fungsinya masing masing.

Investasi adalah suatu kegiatan melakukan penanaman dana atau modal yang dimaksudkan untuk mendapatkan keuntungan di kemudian hari. Sedangkan Pasar Modal adalah suatu tempat dimana berkumpulnya orang yang melakukan investasi atau yang biasa disebut sebagai Investor yang kemudian meletakkan investasinya tersebut pada suatu Instrumen investasi yang diperdagangkan di Pasar Modal. Instrumen yang ditawarkan cukup beragam jenisnya, mulai dari Saham, Warrant, Obligasi, Obligasi Konventibel dan Produk Derivatif lainnya. Masing masing memiliki kelebihan dan kekurangan dimana selain ada keuntungan didalamnya tentu ada resiko kerugian. Kegiatan Investasi ini disebut juga sebagai Penanaman Modal keduanya merupakan hal yang sama secara makna, maksud dan tujuan.

Dalam hal ini Pasar modal harus dibedakan dengan pasar uang, karena pada pasar uang yang diperdagangkan antara lain adalah SBI (Sertifikat Bank Indonesia), SPBU (Surat Berharga Pasar Uang), Commercial Paper Notes, Call Money, Repurchase Agreement, Banker's Acceptence, Threasury Bills dan sebagainya. Hal ini sangat berbeda dengan apa yang ditransaksikan di pasar modal.

Dalam tulisan ini akan dijelaskan seluk beluk Investasi dipasar modal dalam memandang perusahaan yang melantai dibursa dan sekuritas sebagai perantara dibursa, dimana akan dijelaskan bentuk fungsi dan hal-hal penting lainnya yang penting untuk diketahui dalam mengenal pasar modal khususnya pasar modal Indonesia.

Sebelum melihat lebih jauh maka gambaran mengenai Investasi di Indonesia khususnya melalui Pasar modal dapat dilihat dalam 2 (dua) aturan utama yaitu dalam Undang-undang Penanaman Modal Nomor 25 Tahun 2007 dan Undangundang Pasar Modal Nomor 08 Tahun 1998, dalam aturan ini digambarkan dan dideskripsikan apa yang dimaksud dengan perbuatan penanaman modal dan apa yang dimaksud dengan tempatnya yaitu pasar modal.

Jurnal kali ini akan membahas Lembaga yang merupakan pelaku dalam pasar modal yang akan disampaikan dalam 2 (dua) buah deskripsi sederhana untuk diangkat sebagai topik strategis yang akan dibahas dalam pembahasan berikut, yaitu:

1. Apakah Pasar Modal itu?

2. Siapa Investor, Emiten dan Sekuritas dan apa peranan masing-masing?

\section{B. PEMBAHASAN}

\section{Pasar Modal}

Pasar Modal jika kita buat pemahamannya secara garis besar tentang apa yang berlangsung di dalamnya, maka dapat dikatakan bahwa pasar modal adalah sarana yang mempertemukan antara pihak yang memiliki dana untuk tujuan investasi dan pihak yang membutuhkan dana itu atau disini kita dapa mengatakan pihak yang ingin melakukan investasi atau yang memiliki dana lebih untuk diinvestasikan sebagai (surplus fund), sedangkan pihak yang membutuhkan dana karena kekurangan dana tersebut biasa disebut sebagai (defisit fund). Kedua pihak ini memiliki kepentingannya masing masing dan bila yang dimaksudkan dalam transaksi itu adalah 
sebagai suatu kegiatan investasi, maka biasanya dana yang diperdagangkan merupakan dana jangka panjang. Meski tidak menutup kemungkinan banyak di dalam pasar modal yang melakukan transaksi jangka pendek dan ini biasanya disebut sebagai trader, dimana cara kerja trader adalah dengan mentransaksikan saham tertentu lalu mengambil keuntungan dari selisih jual dan belinya.

Pasar modal pada dasarnya adalah sarana bagi pelakunya untuk mencari modal, hal ini khusus bagi emiten dimana emiten akan kita bahas lebih jelas nanti dalam jurnal ini. Modal yang didapat dalam pasar modal sejatinya dimaksudkan untuk menambah modal untuk dibelanjakan sebagai barang modal, meningkatkan produksi, mengembangkan ekspansi yang pada intinya akan meningkatkan kegiatan perekonomiannya dan mengurangi bebannya.

Sebagai suatu sarana investasi sebenarnya pasar modal dapat dilihat dalam 2 (dua) segmen yaitu nonsecurities segment dan securities segment, perbedaan antara keduanya adalah pada nonsecurities segment ketersediaan dana yang didapat oleh perusahaan berasal dari negosiasikan yang dilakukan oleh perusahaan pada lembaga keuangan (misal bank, asuransi, dana pensiun, dan lainnya) yang akan memberikan pinjaman kepada perusahaan dengan perjanjian tertentu dan jaminan tertentu (semisal loan agreement, credit agreement dan lainnya) untuk melaksanakan suatu kegiatan yang spesifik, sehingga pinjaman yang dimiliki hanya dapat digunakan untuk maksud awal yang bukan menjadi dana fresh yang dapat dilakukan untuk melakukan ekspansi yang bebas, di sini artinya investasi yang terjadi tidak dilakukan dengan negotiable securities secara bebas karena hubungannya hanya pada pihak tertentu saja yang melakukan investasi pada perusahaan tersebut. Sedangkan pada securities segment dilakukan dengan bebas dalam suatu bentuk ikut memiliki suatu perusahaan tertentu yang mana hal ini membuat dana yang terkumpul menjadi modal yang tidak mengikat peruntukannya untuk suatu tujuan dalam perjanjian tertentu namun tetap jelas kegunaannya yang mana transaksi ini dapat dilakukan oleh setiap investor.

\section{Investor}

Investor adalah orang perorangan dan atau badan hukum yang menempatkan uangnya untuk diinvestasikan pada suatu bidang usaha maupun bidang lainnya yang dimaksudkan untuk mendapatkan keuntungan di kemudian hari, istilah ini untuk digunakan dalam ranah pasar modal, maka istilah lainnya yang biasa digunakan akan merujuk pada suatu istilah yang lebih spesifik yaitu, Penanam modal yang berarti perseorangan atau badan usaha yang melakukan penanaman modal yang dapat berupa penanam modal dalam negeri dan penanam modal asing.

Seseorang yang menjadi penanam modal di pasar modal akan menjadi penjual dan pembeli dari saham yang ditransaksikan, sehingga investor inilah yang menjadi manifestasi dari pasar di pasar modal tersebut.

Seorang investor di pasar modal, ketika hendak masuk untuk bertransaksi di pasar modal harus memenuhi berbagai macam persyaratan sebagai subjek hukum, baik berupa subjek hukum natural maupun subjek hukum buatan, atau berupa badan hukum, hal ini untuk memenuhi persyaratan subjek hukum dimana subjeh hukumlah yang dapat melakukan suatu perbuatan hukum.

Perbuatan hukum yang umum dilakukan oleh investor di pasar modal adalah perbuatan jual dan beli, perbuatan jual beli ini dilakukan dalam mekanisme yang telah ditentukan oleh pengelola pasar yang dibuat dalam suatu perusahaan khusus yang berbentuk perseroan 
terbatas yang dibentuk khusus untuk itu yang biasa kita kenal sebagai Bursa Efek Indonesia (BEI) yang dalam Bahasa Inggris disebut juga Indonesia Stock Exchange (IDX).

Transaksi yang dilakukan oleh investor untuk melakukan jual dan beli tidaklah dapat dilakukan secara langsung, sebab transaksi yang dilakukan perlu melibatkan perantara yang mana perantara dimaksud adalah perusahaan yang telah mendapat izin sebagai perantara perdagangan saham yang biasa disebut sebagai perusahaan Sekuritas, yang akan dibahas pula dalam bagian khusus dalam tulisan ini.

Investor dalam melakukan transaksi selain harus memiliki perantara juga harus meletakkan dana tertentu sebagai tempat penyimpanan sementara dana yang akan diinvestasikan pasa suatu rekening bank tertentu, yang sudah mendapatkan izin dari pemerintah untuk menjadi penampungan dana investasi, bank sebagaimana dimaksud haruslah memiliki izin sebagai bank kostudian dengan nama produk peletakannya disebut sebagai Rekening Dana Nasabah (RDN), rekening inilah yang nantinya akan menampung dana yang disetorkan Investor untuk ditransaksikan saat investor ingin melakukan transaksi pembelian maupun penjualan atas saham.

Dalam praktek pelaksanaannya investor bisa saja meletakkan dana sementara untuk pelaksanaan investasinya sebelum ditransaksikan di pasar modal dengan tidak menempatkannya di RDN dari Bank Kostudian, melainkan pada suatu Rekening tertentu yang disediakan oleh sekuritas, namun hal ini memiliki suatu keuntungan dan kerugian tertentu. Keuntungannya adalah rekening yang disediakan untuk dipegang oleh sekuritas memiliki imbal hasil bunga penyimpanan yang cukup besar yaitu sekitar $\pm 2 \%$ pertahun dibandingkan dengan RDN dari bank kostudian yang tidak meletakkan bunga pada penitipan dana nasabah. Namun demikian peletakkan dana pada rekening yang disediakan sekuritas juga memiliki resiko dimana resiko tersebut adalah tidak dijaminnya rekening tersebut oleh Lembaga Penjamin Simpanan (LPS) sehingga ada potensi tertentu seperti kehilangan uang jika terjadi force major/ keadaan tak terduga pada dana tersebut karena tidak adanya penjamin atas uang pada rekening non-bank tersebut.

Investor dalam melakukan transaksi di pasar modal, bisa berlangsung antara sesama investor atau penanam modal, selain itu dapat pula dilakukan antara investor dengan emiten, kedua hal ini dibedakan oleh mekanisme atas saham yang diperjualbelikan. Bila yang di maksud adalah transaksi atas saham dari nasabah investor dengan investor, maka saham yang dijual pada prinsipnya adalah saham yang sudah di miliki oleh investor yang akan di jual kepada investor lainnya, hal ini biasanya di perdagangkan di pasar sekunder, dimana peralihan saham yang di lakukan adalah pada pasar umum yang bebas ditawar dan dibeli sesuai dengan mekanisme supply and demand umum dari pasar sehingga naik turunnya harga benar benar berdasarkan permintaan pasar secara umum. Untuk transaksi antara investor selain di pasar umum ada pula perdagangan di pasar Negosiasi yang mana sifatnya tertutup dan pelaksanaan transaksi tidak dilakukan di pasar sekunder umum melainkan di dalam pasar negosiasi sekunder yang mana harga transaksi ditentukan dari konfirmasi investor penjual dan investor pembeli kepada sekuritas masing masing bila transaksi dilakukan antar sekuritas, maupun pada sekuritas yang sama, dan harga yang diterapkan bukanlah berdasarkan harga pasar melainkan berdasarkan atas harga kesepakatan antar investor untuk menjual dan membeli saham dimaksud diantara penjual dan pembeli. 
Selain dari transaksi yang dilakukan antar investor dengan investor di atas, ada pula transaksi yang dilakukan antar investor dengan emiten, hal ini berada pada pasar premier/primer, yaitu proses penjualan saham dari emiten sebagai perusahaan yang menjual saham miliknya pada pasar modal dengan investor sebagai pihak lainnya baik pembeli maupun penjual. Pada pasar primer ini transaksi yang dilakukan adalah sebagai wujud dari Initial Public Overing (IPO) atau bisa juga penambahan jumlah saham emiten, yang biasanya ditandai dengan istilah Right Issue, hal ini merupakan mekanisme perdagangan yang utama karena dengan perdagangan inilah emiten kemudian memiliki modal yang didapatkan dari pasar modal. Terlepas dari emiten yang menjual saham dari perusahaannya kepada investor, ada pula kalanya investor yang menjual sahamnya atas nama suatu emiten kepada emiten yang mengeluarkan sahamnya tersebut, hal ini dikenal dengan istilah buyback oleh emiten. Emiten melakukan mekanisme buyback biasanya dilakukan untuk mengamankan nilai sahamnya yang jatuh di pasar modal, hal ini bisa karena keadaan ekonomi yang sedang tidak stabil ataupun sebab sebab lainnya, namun biasanya bila suatu emiten memiliki opsi atau mekanisme buyback, sebuah emiten tersebut sebenarnya memiliki tanggung jawab yang baik terhadap nilai sahamnya dan kesehatan keuangan yang cukup baik pula, karena untuk melakukan buyback atas saham yang telah dikeluarkan, emiten memerlukan dana yang tidak sedikit dan bukan merupakan suatu opsi bagi perusahaan yang tidak sehat keuangannya.

\section{Emiten}

Emiten adalah sebutan bagi perusahaan yang melakukan penawaran umum atau dikenal juga sebagai Public Offering, konsep ini merupakan suatu konsep yang dikenal di berbagai negara di belahan dunia dan juga dianut oleh Indonesia baik secara hukum maupun pada penerapan perekonomian yang satu dan lainnya tak dapat dipisahkan.

Perusahaan yang dimaksud disini adalah badan usaha yang berbadan hukum, dimana badan usaha yang berbadan hukum di Indonesia terdapat 2 (dua) jenis yang memenuhi kriteria itu, yang pertama adalah Perseroan Terbatas (PT) dan yang kedua adalah Koperasi, melihat konsepsi saham dan besarnya sekala kepemilikan saham itu maka jenis dari perusahaan yang dimaksud mengarah pada Perseroan Terbatas (PT), tidak pada koperasi yang kepemilikan sahamnya adalah kepemilikan saham komunal atau bersama sama dengan hak yang sama bukan berdasarkan kepemilikan saham, apalagi nantinya akan berkembang kearah kepemilikan saham oleh publik, hal ini yang membuat konsep kepemilikan dan anggota koperasi tidak masuk dalam konsep ini karena koperasi adalah badan usaha yang juga badan hukum dimana memiliki aturan yang rata dalam kepemilikannya tidak seperti Perseroan Terbatas (PT) yang besar kecilnya hak yang dimiliki dan besaran keuntungan yang diterima bersasarkan besar kecilnya saham yang dimiliki dimana seorang pemengang saham dapat menjadi pengendali (memiliki hak suara lebih besar) bila memiliki jumlah saham yang cukup besar untuk melakukan itu.

Melihat dari kecocokan konsep saham ini pada perseroan terbatas, maka perusahaan yang akan dimaksudkan dalam jurnal ini kemudian merujuk kepada Perseroan Terbatas (PT). Perseroan Terbatas pada dasarnya tunduk pada UU Nomor 40 Tahun 2007 tentang Perseroan Terbatas ${ }^{1}$, dimana di dalamnya diterang-

1 Undang-undang Republik Indonesia, UU Nomor. 40 Tahun 2007 tentang Perseroan Terbatas 
kan bahwa organ perusahaan atau yang disebut juga perseroan ada 3 yaitu Rapat Umum Pemegang Saham (RUPS), Direksi dan Dewan Komisaris.

Untuk perusahaan yang menjadi perusahaan publik, pada dasarnya tidak ada perbedaan yang terlalu signifikan mengenai peran Rapat Umum Pemegang Saham (RUPS), Direksi dan Dewan Komisaris karena seluruhnya tetap menjalankan apa yang diamanatkan undangundangnya, namun untuk menjadi Perusahaan Publik ada suatu syarat minimum yang harus dipenuhi oleh perusahaan dalam jumlah pemegang saham dan minimal modal yang harus dimiliki untuk dapat dikatakan sebagai perusahaan publik. Maka dari itu perusahaan yang ingin menjadi perusahaan publik akan menjual sahamnya sebanyak yang dipersyaratkan sehingga terpenuhinya setidaknya batas minimum pemilik saham dan jumlah modal minimum yang menjadi aturannya.

Hal ini memiliki implikasi pada organ dari perusahaan tersebut, yaitu pada pemegang saham yang menjadi sangat banyak jumlahnya, hal itu menyebabkan suatu perusahaan yang melantai di bursa menjadi suatu perusahaan publik, meski yang disebut sebagai perusahaan publik belum tentu adalah perusahaan yang melantai di bursa, namun suatu perusahaan yang dapat melantai di bursa harus memenuhi keriteria perusahaan publik dengan jumlah minimal saham dan pemegang saham.

Suatu perusahaan publik, jika ingin melantai di bursa maka harus mengajukan permohonan pada Otoritas Jasa Keuangan dan IDX/BEI yang kemudian diwajibkan untuk segera menyesuaikan anggaran dasarnya menjadi PT Terbuka sehingga dari penyesuaian tersebut diberikan jangka waktu tertentu untuk dapat mengajukan IPO pada suatu sekuritas yang ditunjuknya, Sekuritas yang ditunjuk tersebut baiknya adalah suatu perusahaan sekuritas yang juga merupakan suatu Perusahaan Penjamin Emisi Efek (PEE) dimana nanti sekuritas inilah yang akan memasarkan untuk pertamakalinya dan membagi penjualan atas saham yang akan dipasarkan pada para investor jika jumlah investor yang memesan efek lebih besar dibandingkan jumlah saham yang ditawarkan dengan proporsi tertentu.

Penawaran harga yang ditawarkan didasarkan atas assessment kekayaan asset dan nilai saham perusahaan yang dilakukan oleh appraisal (Penilai Harga) asset perusahaan yang akan mengeluarkan saham ke masyarakat yang kemudian diumumkan dalam suatu prospectus sebagai gambaran bagi investor untuk mengambil keputusan membeli atau tidaknya saham perusahaan tersebut.

Sebuah perusahaan publik yang berniat untuk menjadi perusahaan terbuka (Tbk) perlu memenuhi jumlah modal dan pemilikan pemegang saham tertentu dan hal inilah yang diusahakan dalam mekanisme IPO dimana jika batas minimumnya tidak dapat terpenuhi, maka perusahaan tidak akan dapat menjadi terbuka yang kemudian berkonsekuensi pada diubah kembalinya anggaran dasar perusahaan dari yang terbuka menjadi tertutup.

\section{Sekuritas}

Sekuritas disebut juga sebagai perusahaan efek, yaitu perusahaan yang menjadi perantara di Pasar Modal, bentuk badan usaha dan badan hukumnya adalah perseroan terbatas dengan bidang usaha khusus, perusahaan sekuritas ini harus terdaftar di OJK (Otoritas Jasa Keuangan) yaitu yang menjadi regulator di pasar modal yang saat ini menggantikan Bapepam. Perusahaan Sekuritas ini ada karena orang perorangan ataupun badan hukum yang memiliki dana untuk 
diinvestasikan dan ingin ditanam pada dasarnya tidak dapat bertransaksi secara langsung di pasar modal, hal ini didasarkan pada aturan yang dikeluarkan oleh Bapepam (Badan Pengawas Pasar Modal) dimana kini Instansi tersebut telah berubah dan menjadi OJK (Otoritas Jasa Keuangan).

Bila kita lihat dari kepemilikannya, maka pada perusahaan sekuritas ini dapat dibagi ke dalam 2 (dua) bagian, yaitu adalah Perusahaan Efek Nasional dan Perusahaan Efek Patungan (Join Venture). Keduanya memiliki perbedaan pada sumber modal perusahaannya dimana pada perusahaan nasional keseluruhan dari saham yang disetorkan dan atau dimiliki perusahaan sekuritas bersumber dari investor yang berasal dari Warga Negar Indonesia (WNI) ataupun Badan Hukum Indonesia secara keseluruhan sedangkan pada Perusahaan Efek Patungan, maka sebagian dari sahamnya berasal perorangan WNI, badan hukum asing yang beraviliasi dengannya, badan hukum Indonesia, serta juga dimungkinkan dimiliki oleh badan Hukum Asing yang bergerak di bidang keuangan yang dimana batasan maksimal kepemilikannya adalah $85 \%$ dari modal disetor.

Sekuritas memiliki peran yang sangat strategis dalam mengembangkan pasar modal di Indonesia, dimana sekuritas selain menjadi perusahaan Penjamin Emisi Efek (PEE) dan Perantara/Broker (pialang saham) atau disebut juga Perantara Perdagangan Efek (PPE) dapat pula merangkap Manager Investasi. Hal ini menjadi sangat strategis karena jasa yang ditawarkan tidak hanya kepada nasabah yang menjadi investor namun juga kepada calon emiten dan emiten itu sendiri. Jika ditinjau dari sisi ekonominya sinergi yang dilakukan sekuritas tampak begitu kompleks posisinya yang mana posisinya sebagai underwritter menjadi sangat baik ketika menawarkan dan menjual saham perdana kepada nasabah yang sudah eksisting di perusahaannya, selain dari pada itu juga kepada nasabah umum lainnya yang ingin masuk sebagai pemegang saham dalam perusahaan yang sahamnya sedang ditawarkan secara perdana tersebut.

Suatu perusahaan untuk mampu menjadi perusahaan sekuritas harus memenuhi Modal Kerja Bersih Disesuaikan (MKBD) tertentu, hal ini demi menunjang kelancaran pelaksanaan transaksi perdagangan yang diatur oleh Kementerian Keuangan.

Sekuritas sebagai PEE memiliki beberapa peran strategis untuk membuat suatu emiten menjadi go public, yaitu :

1. Memberikan jasa konsultasi kepada emiten dalam rangka go public;

2. Menjamin efek/saham yang diterbitkan atau di issued oleh emiten;

3. Melakukan kegiatan pemasaran efek yang diterbitkan oleh emiten agar masyarakat investor dapat memperoleh informasi dengan baik dan akurat.

Dari hal tersebut sekuritas sebagai PEE juga memiliki beberapa tipe kontrak penjaminan secara teoritikal ${ }^{2}$ yaitu:

1. Full Commitement (Kesanggupan Penuh).

2. Best Effort Commitement (Kesanggupan Terbaik);

2 Nasarudin, M. Irsan dkk, ASPEK HUKUM PASAR MODAL, Prenada Media, Jakarta Hal. 145 
3. Standby Commitment (Kesanggupan Siaga);

4. All or None Commitement (Kesanggupan semua atau tidak sama sekali).

Hal ini perlu dipahami sebagai bagian yang sangat penting bagi emiten untuk dapat melantai di bursa sehingga mejadi perusahaan terbuka.

Pada sisi lain hubungan sekuritas sebagai pelayan atau server bagi investor memiliki peran yang juga signifikan tak kalah pentingnya dimana informasi IPO biasanya didapatkan investor melalui pemberitahuan pada akun investor di sekuritas, meskipun tidak jarang bahwa informasi itu juga di broadcast di mediamedia mainstream.

\section{PENUTUP}

Pasar modal merupakan tempat bertemunya pemodal yang ingin melakukan investasi pada atau penanaman modalnya paa perusahaan yang memiliki prospek yang baik, dimana pasar modal telah diatur sedemikian rupa dengan sistem yang sudah terkonsolidasi dengan berbagai macam Lembaga yang seluruhnya benjadi suatu kesatuan sistem yang terintegrasi, pasar ini diatur oleh suatu Otoritas yang bernama Otoritas Jasa keuangan, beberapa bagian diatur oleh kementrian keuangan dan di manage oleh suatu lembaga yang ditunjuk bernama Bursa Efek Indonesia.

Para pelaku pasar modal terdiri dari banyak bagian diantaranya adalah penanam modal atau yang disebut juga sebagai investor yang merupakan pasar/ market dari pasar modal dan segala macam transaksi yang dilakukan bermula dan berakhir pada investor, baik dari emiten kepada investor maupun investor pada investor lainnya.

Emiten merupakan perusahaan yang melantai di bursa yang menjual sahamnya dalam bentuk saham kepada penanam modal dengan bantuan sekuritas yang mana emiten bila telah melantai di bursa maka disebut sebagai perseroan terbatas Terbuka atau (PT. Tbk.), sedangkan sekuritas adalah perusahaan yang menjembatani keduanya antara emiten dan investor agar dapat terhubung dan bertransaksi dengan baik.

\section{DAFTAR PUSTAKA}

A. Abadurrahman. Ensiklopedia Ekonomi Keuangan Perdagangan, Pradnya Pramita, Jakarta, Cet.6, 1991.

Balfas, Hamud. Hukum Pasar Modal, Tata Nusa, Jakarta, 2006.

Fuady, Munir. Pasar Modal Modern (Tinjauan Hukum), Citra Aditya Bakti, Bandung, 2001.

Iskandar, Irfan. Penghantar Hukum Pasar Modal Bidang Kustodian, Djambatan, Jakarta, 2001.

Nasarudin, Irsan dan Surya, Indra, Aspek Hukum Pasar Modal, Kencana Preneda Media Group, Jakarta, 2006.

Sitompul, Asril. Pasar Modal, Citra Aditya Bakti, Bandung, 2000. 
Sitompul, Asril. Reksa Dana Pengantar dan Pengenalan Umum, Citra Aditya Bakti, Bandung, 2000.

Soemitra, Andi. Masa Depan Pasar Modal Syariah di Indonesia. Edisi: Pertama, Prenada Media Group, Jakarta, 2014.

Sunariah, Penghantar Pengetahuan Pasar Modal, (UPP) AMP, Yogyakarta, 2003.

Umam, Khaerul. Pasar Modal Syariah, Pustaka Setia, Bandung, 2013.

Umam, Khaerul. Pasar Modal Syariah dan Praktik Pasar Modal Syariah, Pustaka Setia, Bandung, 2013.
Widiatmodjo, Sawidji. Cara Sehat Investasi di Pasar Modal, Jurnalindo Aksara Grafika, Jakarta, 1 